\title{
Large format design: full body ceramic tiles and their application in architectural design
}

\author{
Emilia Malec-Zięba \\ https://orcid.org/0000-0002-0296-5223 \\ emi.arch@op.pl \\ Faculty of Architecture and Fine Arts, Andrzej Frycz Modrzewski Kracow University
}

\begin{abstract}
In the $21^{\text {st }}$ century, a distinct technological progress has taken place with regard to ceramic tiles production. Both technological possibilities and the scope of application of the said material have improved. Full body ceramic tiles have started to appear in architecture not solely as a surface covering materials for concrete but also in applications that had not been earlier associated with ceramic tiles. This article focuses on approaching this subject in the context of the usage of large format porcelain stoneware tiles in the shaping of architecture. In this contemporary era, we are experiencing an exceptional evolution, on both technological and aesthetic aspects, when it comes to the production of ceramic materials, specifically porcelain stoneware tiles. Modern ceramic products, especially large format ceramic tiles, also referred to as siliceous sinter, offer nonconventional possibilities in design and an extended scope of applications of this material in architectural realizations.
\end{abstract}

Key words: architecture, innovative ceramics technologies, gres porcellanato, porcelain stoneware, siliceous sinter, large format ceramic tiles

\section{Introduction}

The exceptionally fast pace of progress in production technology, technical and aesthetic parameters regarding full body ceramic tile has led over the recent years to the creation of a new kind of porcelain ceramic tiles providing innovative properties and formats of 1,500 $\times 3,000 \mathrm{~mm}$, and 3-5 $\mathrm{mm}$ thick [1]. Due to their new properties, large format ceramic tiles are highly inspirational and interesting material that allows it to meet diverse architects', designers' expectations and users. The growing popularity of this product increased its usage more often in a wide range of areas both in architecture and interior design [7].

This article focuses on presenting unique, innovative possibilities related to the usage of large format full body ceramic tiles in the shaping of architecture and interior design elements.

This subject is also related to the research task conducted by the Author (research task WAISP/DS/7/2018) at the Faculty of Architecture and Fine Arts, Andrzej Frycz Modrzewski Krakow University.

\section{Innovative ceramic technologies: full body ceramic tiles}

Innovative technologies in ceramic material production broaden modern technical and aesthetic possibilities of the usage of large format full body ceramic tiles, which are specific material. Full body ceramic tiles production technology is developing at a very dynamic pace. At first, porcelain stoneware was an integral material without a glazed surface; however, manufacturers aimed at inventing a product that would combine traditional tiles with glaze coating to improve strength parameters and aesthetics. In 1995, glazed porcelain stoneware started being produced; it became a highly popular material and triggered the development of this technology. Nowadays, integrally coloured porcelain stoneware is the most popular type. There are several types of ceramic tiles: technical, glazed and integrally coloured ceramic tiles [2]. 
Technical ceramic tiles is a full mass sinter from $8 \mathrm{~mm}$ to $2 \mathrm{~cm}$ thick, which most often comes in $30 \times 30 \mathrm{~cm}$. This material is not subject to further finishing processes particularly concerning aesthetics and is of a typical beige-grey hue with clear dark kernels. Due to its high durability, resistance to stains and elevated anti-slip parameters, it is used as floor covering mainly in technical rooms [9].

Glazed porcelain stoneware is material whose base has natural colour, while on the surface glaze with a graphic pattern is applied, covering the base [2]. Glazed porcelain stoneware tiles resemble regular ceramic tiles, yet they surpass them in terms of durability, whereas the top glaze layer secures tiles against permanent stains. This material is available in a wide range of colours and patterns. Due to the possibility of the glaze undergoing a mechanical damage, as such tiles are not recommended for technical or industrial rooms.

Integrally coloured porcelain stoneware is tail whose base serves as the foundation, while the colour alone is applied to selected location only. This technology called the double loading method allows one to obtain, by means of skilful mixing of layers, wide decorative possibilities and visual depth. Its advantages include excellent technical and utility parameters as well as beautiful colour palette and tonal patterns. It mimics perfectly the natural stones in three options of surface finishes: matt, polished and structural [3]. These types of ceramic tiles are produced in a wide range of sizes and colours, and since there is no layer that could be subject to abrasion, they can be allied in intensely used interiors.

In the evolution of the full body ceramic tile production process, an additional advantage was the introduction of rectification, that is, a process consisting in cutting off and polishing tile edges in a mechanical manner, so that an identical size and smooth edge are obtained for all elements. This method has allowed tiles to be installed with the minimum grout line, thus obtaining the effect of a homogeneous and uniform surface.

Ceramic tile production using traditional moulding technology, where moulds and stamps are put to use, bears significant restrictions regarding size and economy of production. The new technology breaks these production barriers and is characterized by high elasticity in large size tile manufacturing. It allows one to create modular products not limited by size, consistent in terms of design, offering at the same time the possibility to use various decorative effects [4].
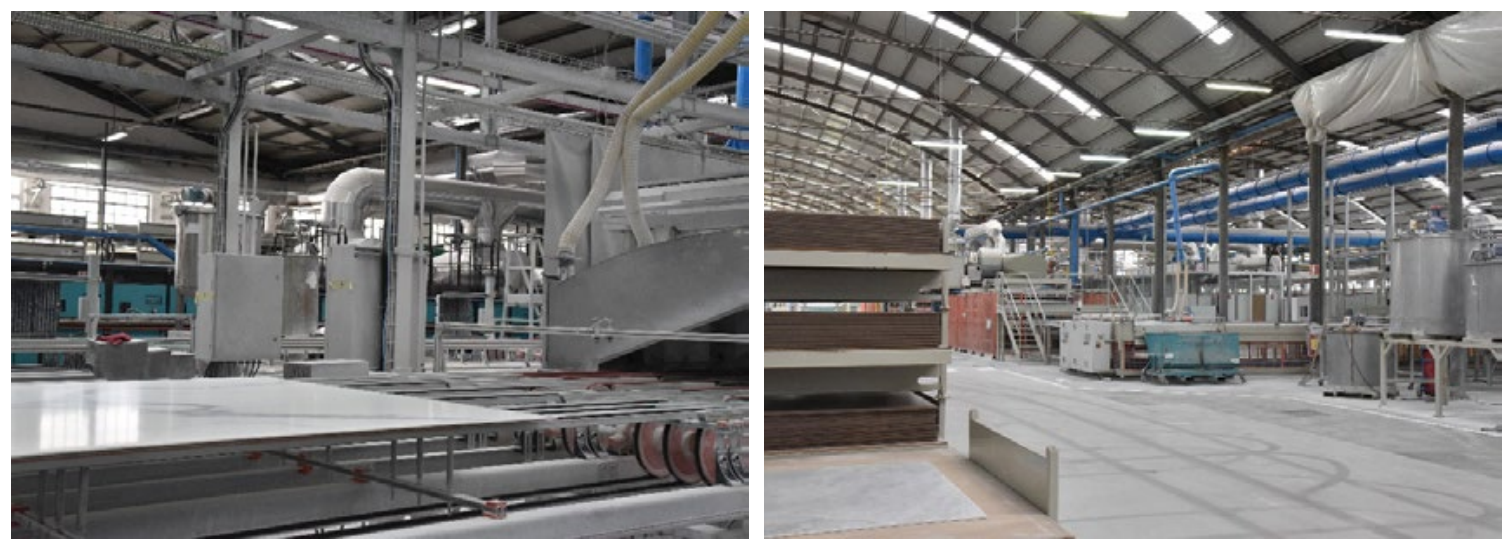

Fig. 1. Continua + production line, Fiandre Architectural Surfaces production plant. (Source: the Author's own archives)

The top-edge technology available at present in the ceramic technology is the system called Continua+ [8]. Developed by Sacmi, an Italian producer and world's leader in ceramic manufacturing machines and appliances, Continua + production system is the cutting-edge technology for making full body ceramic tiles and tiles of various sizes and thicknesses. The revolutionary technological line Continua is already used in most porcelain stoneware production plants. This system allows one to manufacture porcelain stoneware without using conventional press and form with higher efficiency than the traditional production lines. Porcelain tiles are obtained in a wide range of dimensions, particularly in large formats and of various thickness as well as with various types of surface finish. Owing this to the patented DDD (Digital Dry Decoration) technology, Continua+ allows one also to take full advantage of the potential of digital design, providing innovative aesthetic effects [8].

This technology ensures products of perfect quality and aesthetic value, the possibility to control the production process and full quality control on every stage of production. 
Porcelain stoneware (gres porcellanato) ${ }^{1}$, also called siliceous sinter or porcelain stoneware, is a composition of natural minerals, particularly quartz, silt, granite rocks and ceramic pigments, whereas its different names above come from proper names used in various production plants where this material is manufactured [10]. Porcelain stoneware is a compact, durable and non-porous ceramic material. These tiles are characterized by numerous advantageous properties such as compact microstructure, low porosity, considerable durability, low susceptibility to abrasion, high bending resistance, resistance to chemicals and low temperatures [5].

Full body ceramic tiles are:

- chemically resistant,

- easy to clean,

- resistant to abrasion, damage, scratching,

- frost-proof,

resistant to fire and high temperature,

- UV resistant,

- flexible

- stain-resistant,

- easy to process,

quick to install,

- aesthetic (they ensure minimal grout line installation and a natural look),

- environmentally friendly (LEED certificate, Hydrotec system) [11].

- large format

(2) MINIMAL THICKNESS
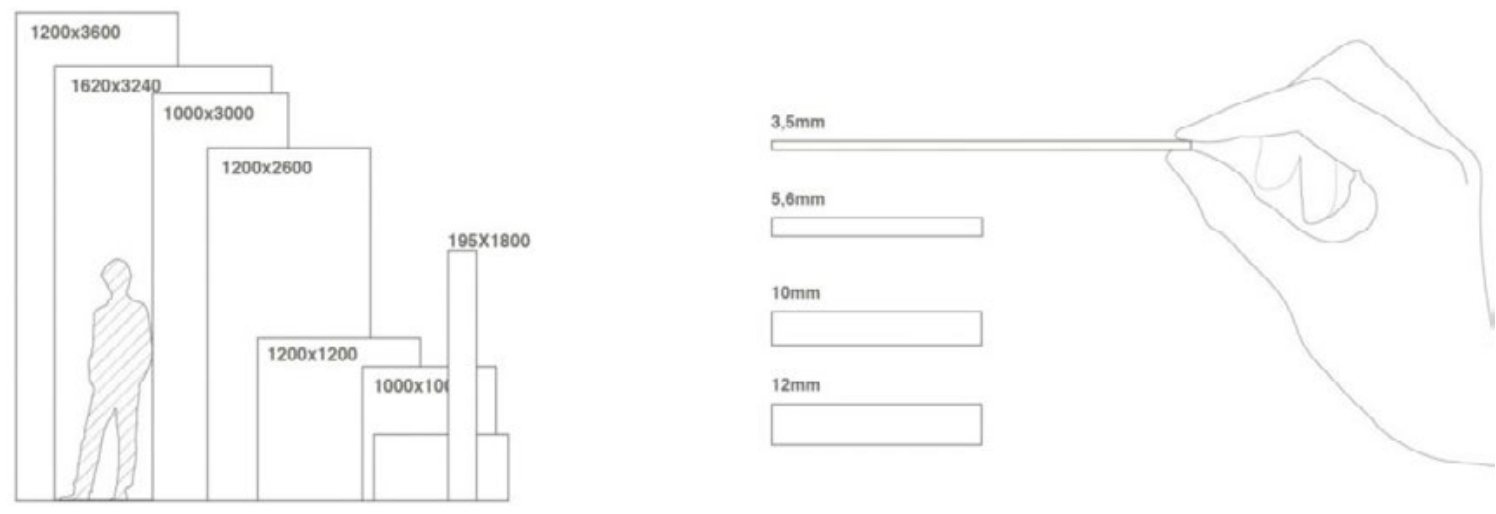

Fig. 2. Formats and thickness of porcelain stoneware tiles, own study based on information materials: https://www.coverlambygrespania.com/pl/coverlam/producto/ [accessed on 24.02.2020]

Full body ceramic tile is actually a natural product and its components are obtained in a sustainable manner. This material does not emit any substances into the environment and can be easily ground and then subject to recycling processes for future use in other production processes.

Porcelain stoneware tiles made of masses in the form of pellet are formed on hydraulic presses under high pressure $(450 \mathrm{kgs} / \mathrm{sq} . \mathrm{cm})$, and then fired at very high temperature $\left(1220^{\circ} \mathrm{C}\right)$ [5]. Due to the innovative production technology, large format Full body ceramic tiles are made available today in the formerly non-existent size of up to $320 \times 160 \mathrm{~mm}$ and thickness from 3 up to $12 \mathrm{~mm}$. A square metre of the tile weighs only $8 \mathrm{kgs}$. These tiles are ideally flat and can be cut to custom size with utmost precision [12]. In raw professional terms, large format tiles are tiles that are over 1600 sq. cm large.

1 Porcelain stoneware (gres porcellanato), is a material that now functions under many names - quartz sinter, large format full body ceramic tiles, porcelain stoneware, means all the time the same material, made of pressed and fired minerals, produced in very large formats and extremely small thickness. Separate names are due to the own names used in the different factories producing this material. Based on the text on:https://www.oskarjursza.com/2018/01/czy-spieki-kwarcowe-sa-gresem.html [dostęp24.02.2020] 
Technical parameters of these tiles make them competitive to other finishing materials, including natural stone, glass or wood. Owing this to the digital printing technology ceramic tiles can imitate virtually any product (stone, wood, metal, concrete) and also bear patterns that cannot be found in nature. Furthermore, the applied 3D effect lends a three-dimensional structure to the tiles that play with contrast, light and shadow.
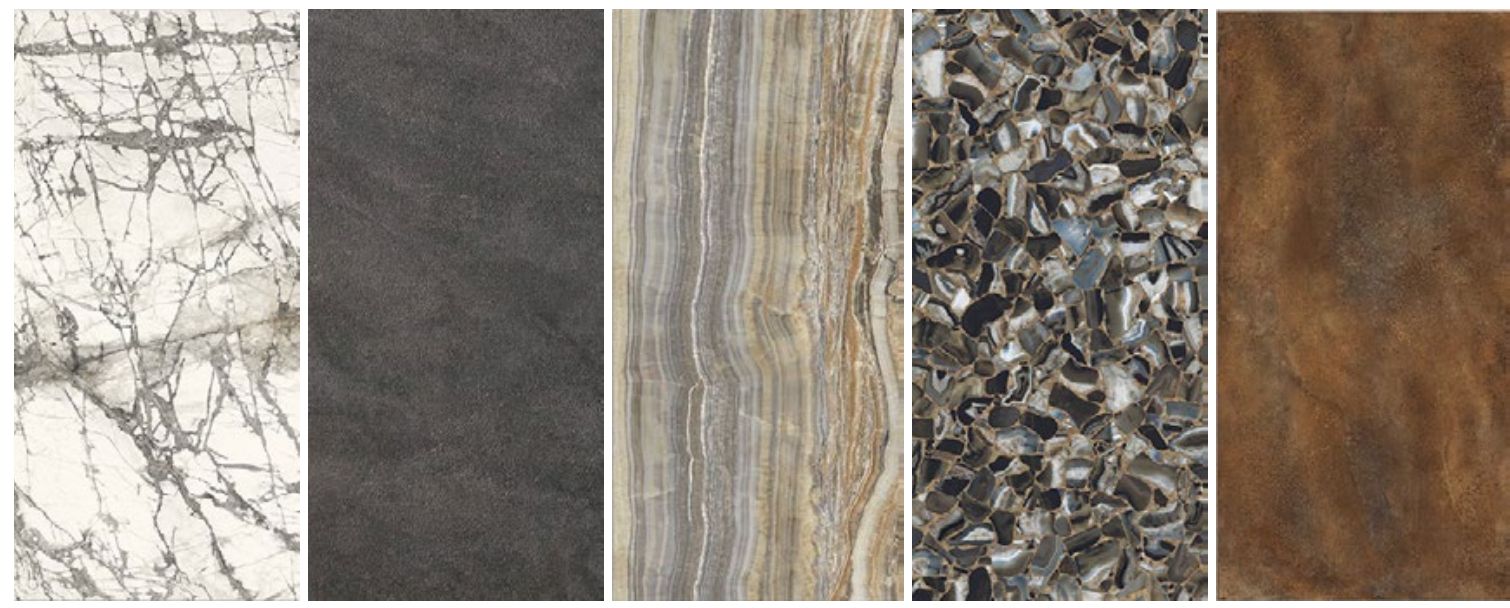

Fig. 3. Colours and textures of full body ceramic tiles, own study based on information materials: https://www.irisfmg.com/ porcelain-tile/maxfine/marmi-maxfine/ [accessed on 24.02.2020]

It is possible to additionally use on sinters a special Hydrotect ${ }^{2}$ layer, which makes this product ecological and innovative. Tiles with this layer clean themselves, are anti-bacterial, eliminate bad odours and even clean the air. This is all possible owing to the fact that the patented product added to the glaze contains titanium dioxide (TiO2), which, being a catalyst, triggers a photocatalytic reaction and a release of active oxygen from water in the air. The system of operation of the layer is based on the principle of photo catalysis. Natural cleaning is initiated by the power of natural or artificial light followed by the active surface generating a reaction that cleanses the material surface off dirt. It reduces the amount of bacteria and unpleasant odours, it also activates the reaction capable of breaking the impurities present in the air then allows it all to be eliminated by rainwater. Since the substance in the glaze is a catalyst of the reaction that takes place is not used entirely and these special properties of tiles are permanent [13].

\section{Large Format Design}

In the $20^{\text {th }}$ century, tiles were used as a finishing material for concrete, yet along with the technological development new parameters were successfully created for tiles so that they could be thinner, more durable. They come in larger formats and as such allow new application of tiles to be discovered. Due the development in porcelain stoneware production whose pace has improved in the recent years, a product appeared. It started being used not only as a traditional finishing material, for example, kitchen or bathroom tiles, but it has been also introduced in solutions for creating interior and architectural elements, such as countertops and elevations At present, full body ceramic tiles are no longer materials attributed only for floors or walls finishing. Porcelain stoneware is a universal product that qualifies as a covering for both horizontal and vertical surfaces. Due to availability of tiles in increasingly bigger sizes and countless technical and aesthetic solutions, this material ideally adapts to all design concepts additionally, due to the easy processing and increasing accessibility (both in terms of price and construction work) it became an innovative material presently applicable to architecture and architectural interiors.

2 Hydrotect is a unique technology by a Japanese company Toto (world's pioneer in photocatalytic technologies) used on the licence by various ceramic tile manufacturers. Hydrotect technology is a unique self-cleaning protective layer. The name Hydrotect used by Laminam, Bios Ceramics (Bios Self-Cleaning, Bios Antibacterial) used by Casalgrande Padana, Active Clean Air\&Antibacterial Ceramic by Iris Ceramica Group, or H\&CTiles by Grespania is the very same system but under a different name. 
Siliceous sinter tiles are characterised by very high strength, but also modern design. For this very reason, their possible application is unlimited. It is a material that can be used literally anywhere, both indoors and outdoors. When applied on elevations, it can move into the interior in a smooth manner. It can be applied both on floors and on walls, as a finishing material in furniture or other furnishings, offering a homogeneous effect.

Large format full body ceramic tiles are a material that sparks increasingly more interest among architects and designers. Due to innovative technologies, it is increasingly easier to implement even the most daring concepts and visions. The new technology has changed the way of thinking about design. Modern ceramic products have given unconventional possibilities for implementing this material and a wider scope of its usage in architecture and interior design [6]. Today, porcelain stoneware tile becomes more and more often a fully-fledged architectural element and a stand-alone compositional material. The transfer of stone, wood or plant motifs onto large format tiles has marked the beginning of completely new solutions and results applicable in interiors. New formats called mega-formats or XXL tiles offer completely new possibilities [7]. Siliceous sinter tiles started appearing in interiors that have not been previously associated with this material, such as bedrooms and living rooms. They have become one product with multiple applications, as a material for interiors for floors, walls, furniture or other furnishings, but also as a material for outdoors for elevations, terraces, footpaths or street furniture. The $160 \times 320 \mathrm{~cm}$ format is an interesting innovative solution that offers the possibility to fill a wall up from the floor to the ceiling with one material only, which is resistant to dirt, resilient and decorative at the same time. It ensures an effect of homogeneity of the material with the minimum grout line.

At present, the use of sinter tiles is highly popular in executing architecture and interior design elements. There are numerous contemporary examples of this kind of solution.

\section{Selected examples of implementation using large-sized full body ceramic tiles}

Large-sized ceramic tiles are a material of increasing interest of architects and designers. Innovative technologies make it easier to implement even the most bold concepts and visions. New technology has changed the way we think about design. Modern ceramic products have given unconventional possibilities of implementation and extended scope of application of this material in architecture and interiors. Today, porcelain stoneware is increasingly a full-fledged architectural element and an in-itself compositional material. For the presentation, projects distinguished by innovative solution and form, created in the last ten years, were selected.

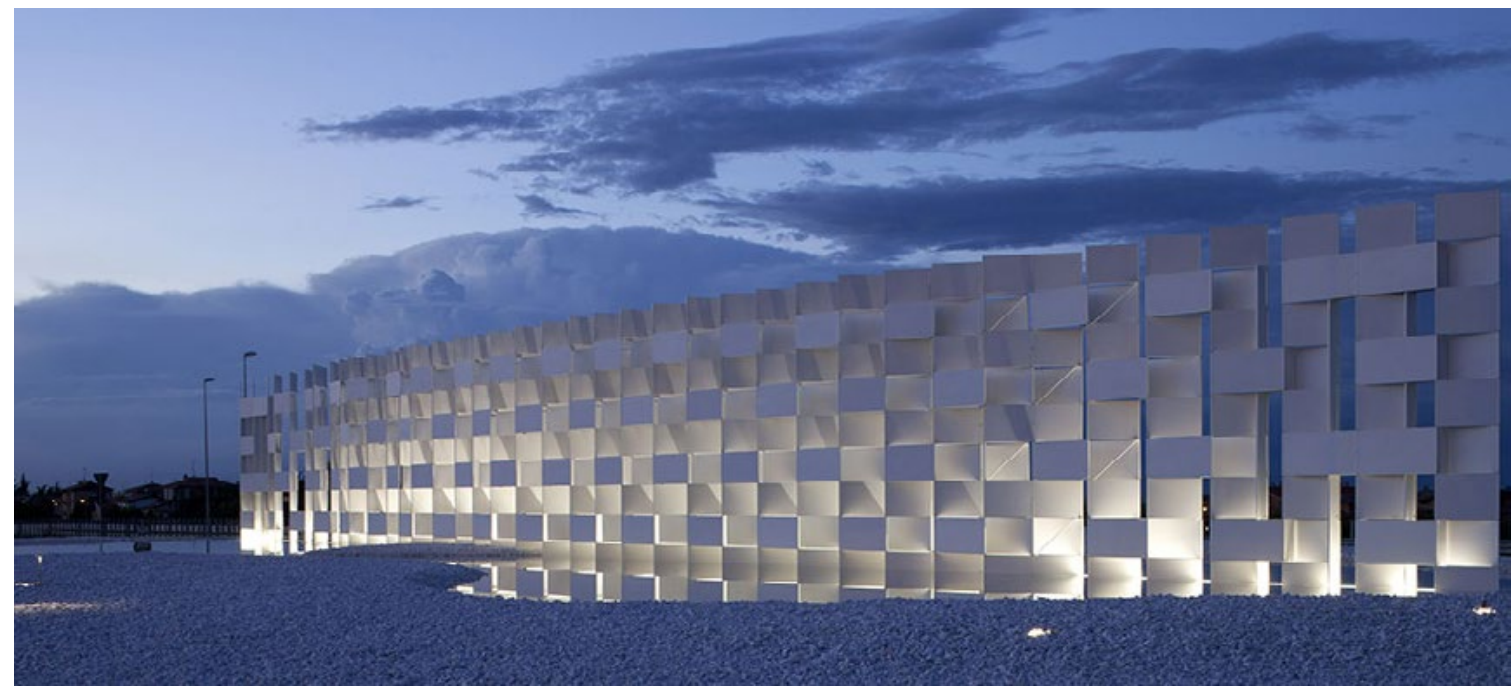

Fig. 4. Casalgrande Ceramic Cloud: https://www.casalgrandepadana.com/en/magazine/detail/casalgrande-padana-e-kengo-kuma-realizzano-casalgr/ [accessed on 20.11.2020] 
Casalgrande Ceramic Cloud - Ceramic Cloud - this work of Kengo Kuma was created in Italy for Casalgrande Padana on the occasion of the $50^{\text {th }}$ anniversary of business, in 2010. The CCCloud incorporates ceramic tiles with steel structures to create a sculptural work of ceramic tile art free from substrates. The entire installation is 45 meters long, 7 meters high and in the central section reaches a width of $1.7 \mathrm{~m}$. For the first time, the ceramic material has been used here as a structural element. The architect wanted to avoid the conventional use of this material as a so-called cladding. The construction method liberates the monument from the traditional concrete substrate in order to give it lightness and transparency. The structure is comprised of 526 elements, each consisting of two $600 \times 13 \mathrm{~mm}$ pressed tiles with varying lengths up to $1200 \mathrm{~mm}$. [1]

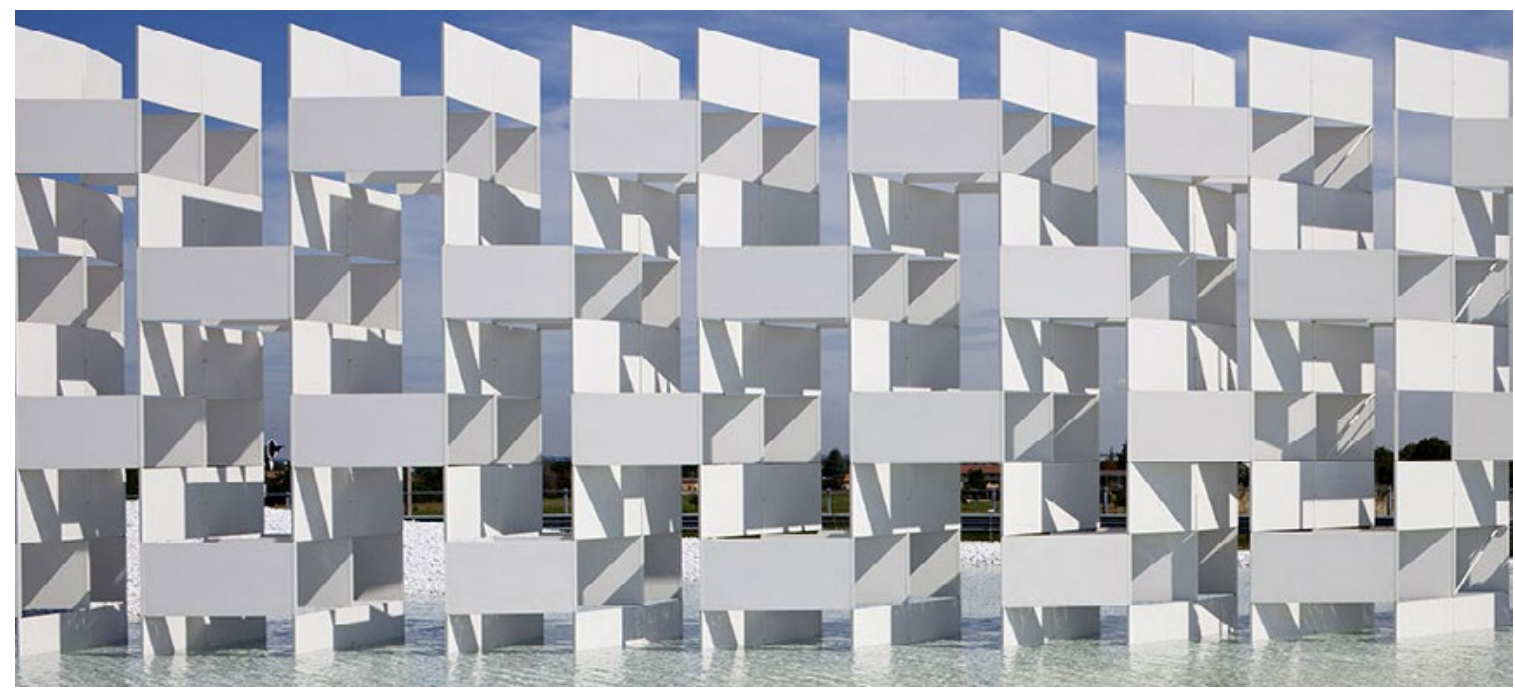

Fig. 5. Casalgrande Ceramic Cloud: https://www.casalgrandepadana.com/en/magazine/detail/casalgrande-padana-e-kengo-kuma-realizzano-casalgr/ [accessed on 20.11.2020]

The monument took the form of an artificial "cloud" floating in a reflection pool. The form gives the impression of a light, detached from the ground, which is somewhat in constant motion. The resulting composition looks like an architectural object and gives the impression of being dynamic although it is static.
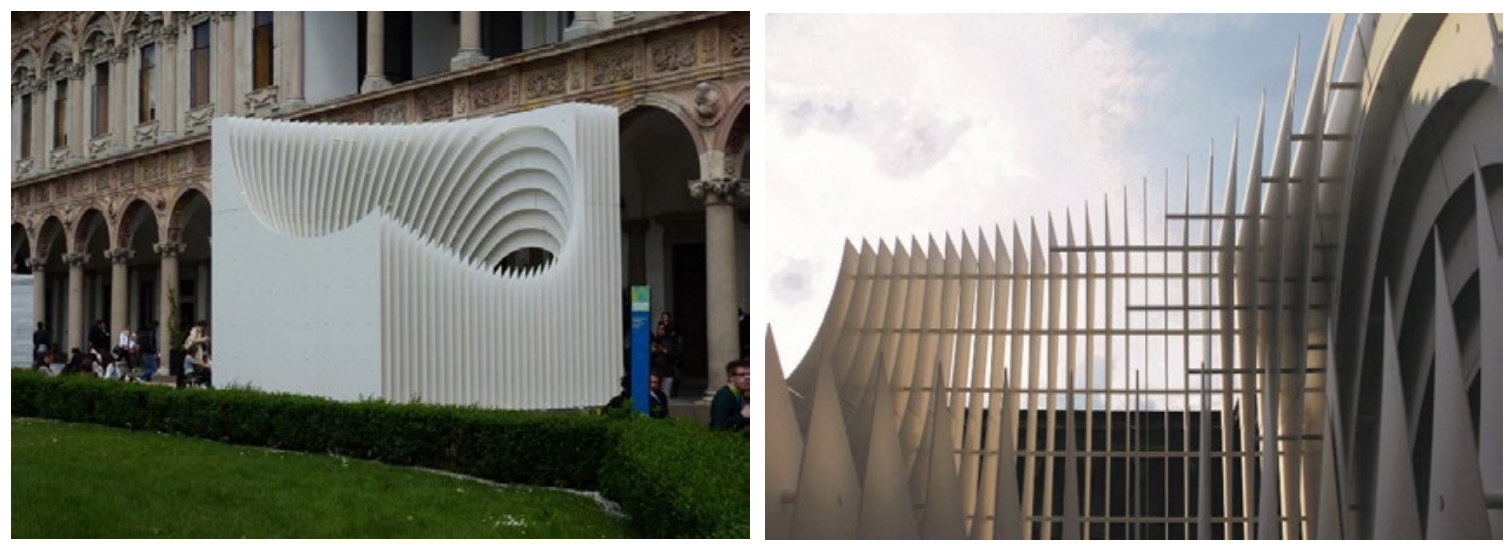

Fig. 6. 3DX1: https://www.odiledecq.com/projets/3d-x1/ [accessed on 20.11.2020]

3DX1, was designed by Odile Decq for the Fuori Salone 2012 Milan Design Week. Ceramic manufacturer Fiandre partnered with the architect to showcase their large format ceramic tile line Maximum $(300 \times 150 \mathrm{~cm}$ with thickness of 3 to $6 \mathrm{~mm}$ ). Abandoning the traditional use of the ceramic tiles as surface covering, Decq drew attention to the paper thin ceramic, both its suppleness and its strength. The resulting sculpture is a cube divided into 31 slices spaced $150 \mathrm{~mm}$ apart. A single slice of the $4.5 \times 4.5 \times 4.5 \mathrm{~m}$ cube is comprised of four and 
one-half $3,000 \times 1,500 \mathrm{~mm}$ white tiles. The entire sculpture comprises a total 140 tiles. In developing the assembly, the architect relied on the manufacturer's knowledge of the flexibility and strength of the material in order to create the grid of supporting rods. Threaded steel rods were assembled in segments on a $500 \mathrm{~mm}$ grid in order to provide stability to the structure. Odile Decq chose large sized full body ceramic slabs for its extraordinary potential for design and architecture permitting unlimited solutions[1].
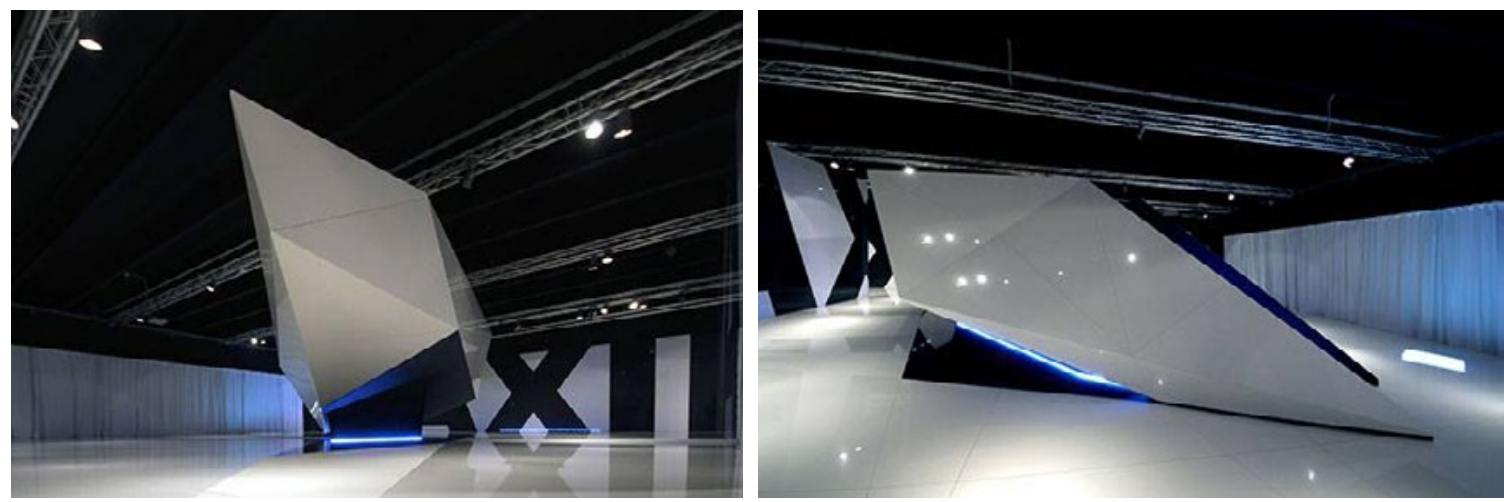

Fig. 7. Showroom Maximum: https://www.granitifiandre.com/news/new-maximum-showroom-opens [accessed on 20.11.2020]

Showroom Fiandre Maximum, for Graniti Fiandre factory in Castellarano, Italy, is a project of the Polish Medusagroup studio from 2013. Presented new product size $(150 \times 300 \mathrm{~cm}$ plate at $6 \mathrm{~mm}$ thickness) required an approach that would present Maximum tiles in a new light, will show the scale of the product, its excellent quality and the possibility of creative application. It inspired designers to experiment with new forms and new expressions. The architects designed a floating dynamic object, which can be accessed by the stairs located in it and watch the exposition presenting the size and colour of the tiles. Lukasz Zagala and Przemo Lukasik of Medusagroup proved to be up to the challenge: "Designing the Maximum showroom was a great pleasure for us because of the opportunity it offered to rethink the unexplored potential of a new ceramic material. Maximum tiles, with their exceptional size, are an extraordinary resource for creating architecture. It would be impossible to design a showroom for Maximum tiles which was limited to simply covering surfaces. This is why we decided to design a sort of fluctuating, dynamic object which could be visited and would offer a different point of view. An opportunity to state the manifesto of Fiandre's goals with a concrete example: Maximum is contemporary, pure, clean and elegant"[16].
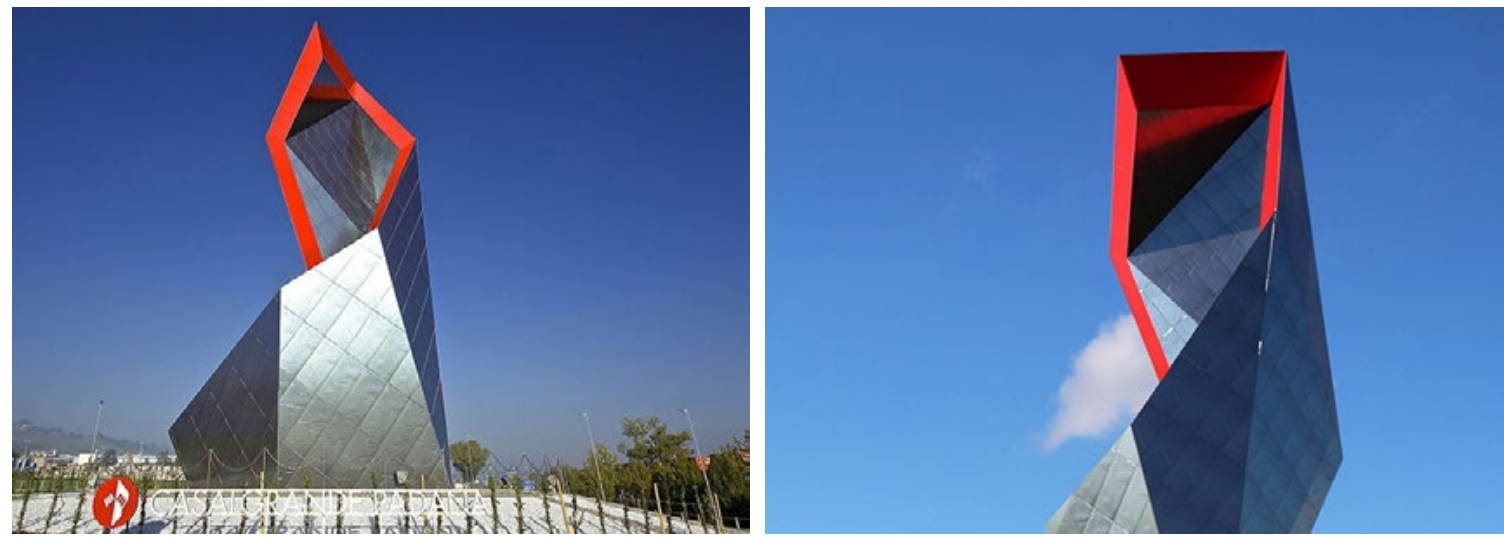

Fig. 8. Casalgrande Ceramic Crown: https://www.casalgrandepadana.com/en/magazine/detail/casalgrande-ceramic-crowndaniel-libeskind-il-land/ [accessed on 20.11.2020]

Casalgrande Ceramic Crown, an architectural structure is a spectacular landmark designed by the architect Daniel Libeskind in 2015[17] . The inspiration behind the Crown was the idea of using verticality to create 
a new point of artistic reference in the area around the Casalgrande Padana complex. It's a truly expressive shape with multiple different perspectives at play and lines that seem to rotate on the vertical axis of a spiral that grows on itself, reaching a height of 17 metres. The entire structure is covered with $300 \mathrm{~m}^{2}$ of three-dimensional ceramic tiles characterised by a fractal motif, which Libeskind designed especially for Casalgrande Padana. The ceramic tile cladding is dry-anchored to a substructure fixed to the main steel structure frame of the monolith using the ventilated façade technique. The resulting ceramic covering covers the 28 sides of the Crown, each of which offers different shaping and inclines.

The Crown is therefore an experimental installation of notable interest and perspective, because it takes typical ventilated façade assembly and applies this technique would not usually be applied for.

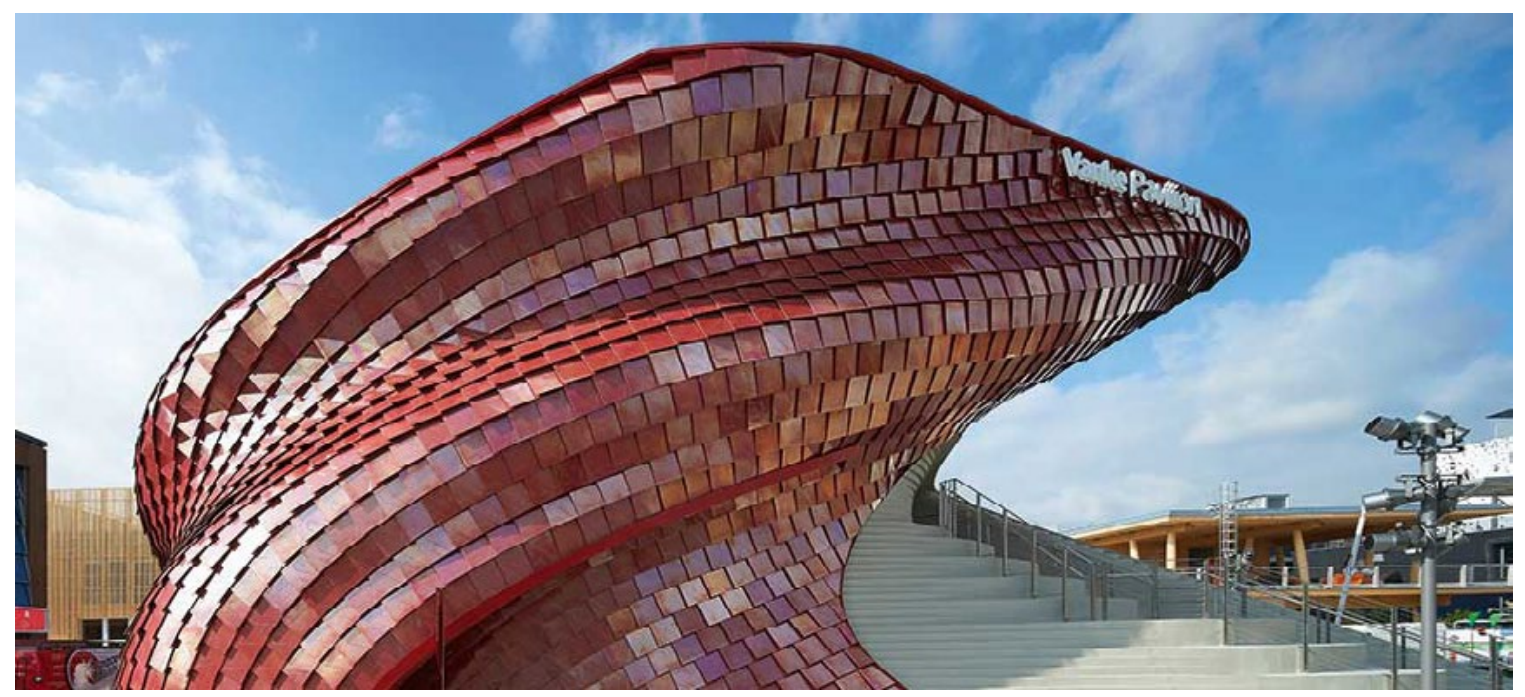

Fig. 9. Vanke Pavilion: https://www.casalgrandepadana.com/en/magazine/detail/successo-delle-lastre-casalgrande-padana-con-vanke/ [accessed on 20.11.2020]

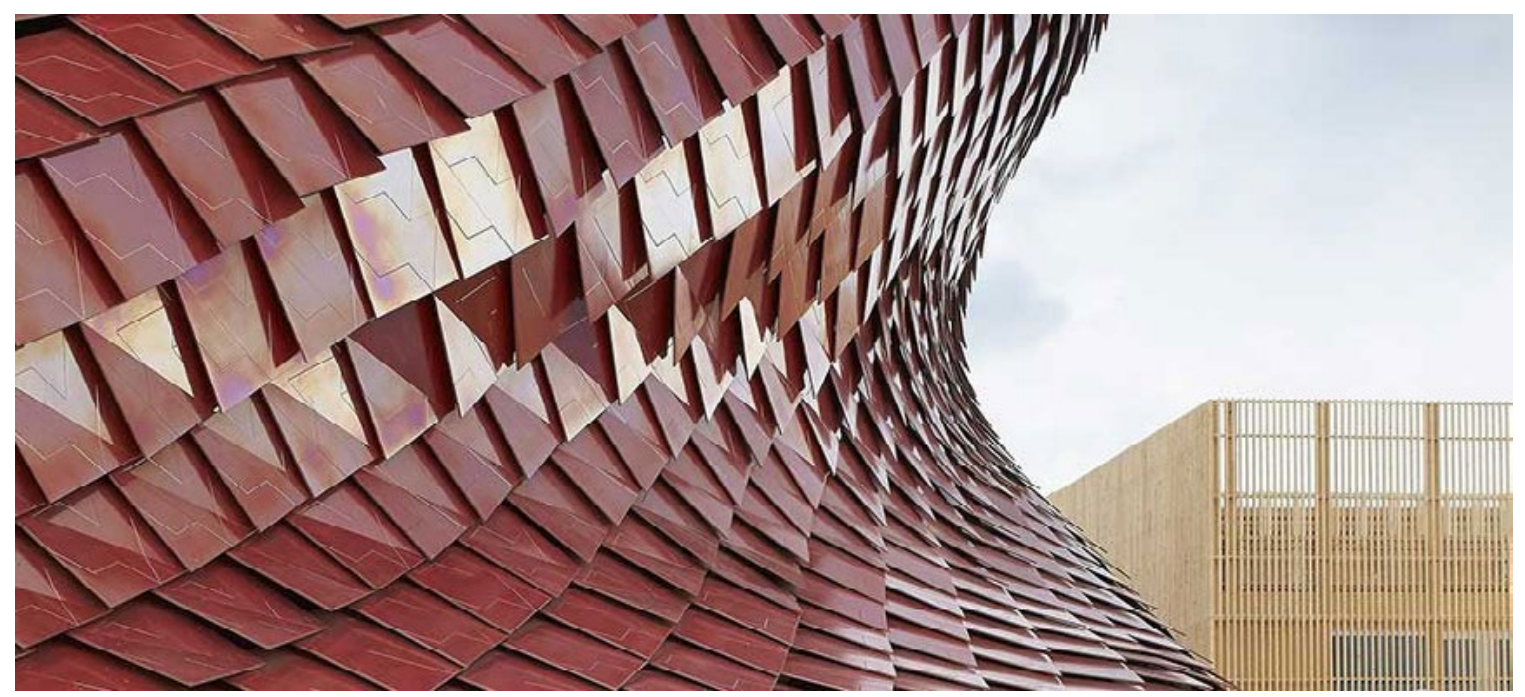

Fig. 10. Vanke Pavilion: https://www.casalgrandepadana.com/en/magazine/detail/successo-delle-lastre-casalgrande-padana-con-vanke/ [accessed on 20.11.2020]

Vanke Pavillion, it's designed by the architect Daniel Libeskind, the corporate pavilion for Vanke china designed for Expo 2015 in Milan[18]. The temporary pavilion had 800-square meter and forming a dynamic, vertical landscape. Daniel Libeskind succeeded in bringing to life a spectacular organic shape with a surface spanning 
$578 \mathrm{~m}^{2}-36$ meters long, $19 \mathrm{~m}$ wide and $12 \mathrm{~m}$ high. The design features a sinuous geometrical pattern that flows between inside and out, while a grand staircase - clad in warm grey concrete - carves through the red serpentine form and guides visitors to the upper level. the pavilion is clad with more than 4,000 red metalized tiles that Libeskind designed with the Italian company Casalgrande Padana. The geometric ceramic panels not only create an expressive pattern that is evocative of a dragon-like skin, but also possess highly sustainable self-cleaning and air purification properties. the three-dimensional surface is coated with a metallic coloration that changes as light and viewpoints shift. The tiles are installed with a state-of-the-art cladding support system that gives a rhythmic pattern and mathematical form to an otherwise supple, curved shape. The project opens up new frontiers of design and technology in the field of architectural covering solutions.
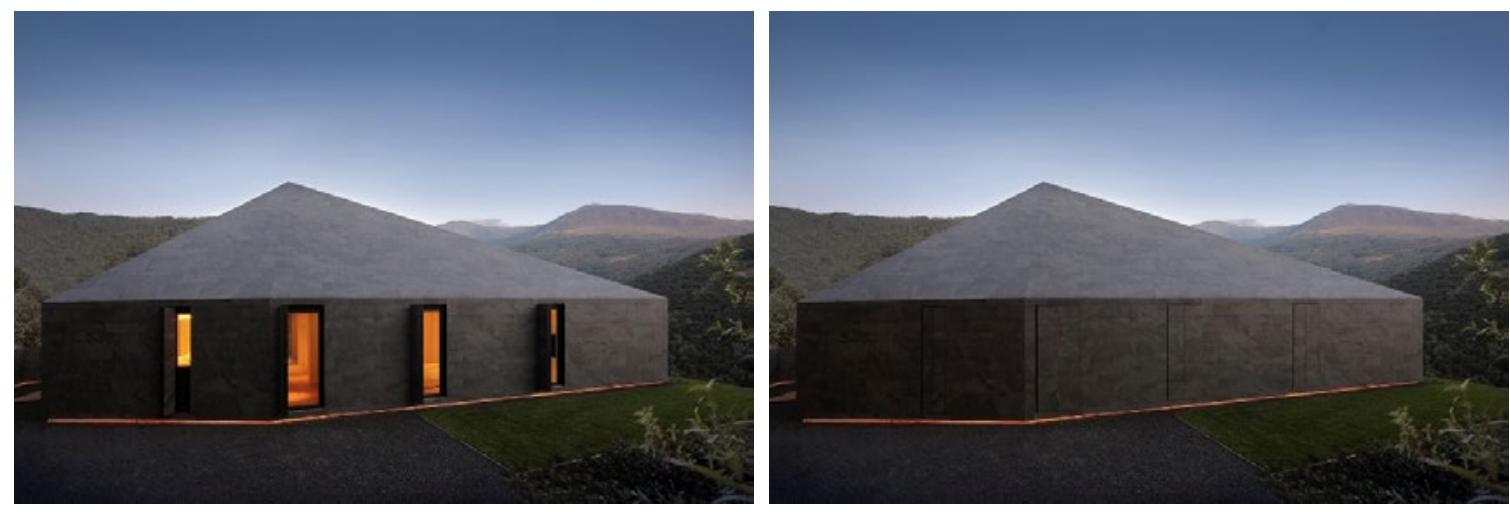

Fig. 11. Montebar Villa: https://www.casalgrandepadana.com/en/projects/r/montebar-villa-jm-architecture-jacopo-mascheroni/ [accessed on 20.11.2020]

Montebar Villa, designed by Jacopo Mascheroni - Architektura JM, won a first price in the tenth edition of the Casalgrande Padana Grand Prix in 2016 year, in the category of residential buildings[19]. It's located in Medeglia, in Switzerland. This project skillfully expresses the idea of a house with a pitched roof with a contemporary approach. There is an unusual, experimental solution adopted for the ceramic cladding, which entirely covers each vertical and inclined surface to create a monolithic, mono-material and monochrome architectural style. It looks like a stone in the landscape. The exterior of Villa Montebar was completely covered with porcelain stoneware slabs also floor and wall inside. The cladding material that unifies the building's surface is a ventilated façade with porcelain stoneware tiles and an invisible fastening system. Every face of the shell has been designed tile by tile, with a dynamic pattern composed with three different formats, and many tiles have mitered edges. The same porcelain stoneware material has been applied to the custom designed folding shutters, to match and align with the façade pattern when they are closed. The structure itself and the attention to the finer details mean that the compositional and application potential of the porcelain stoneware used is fully realised[20].
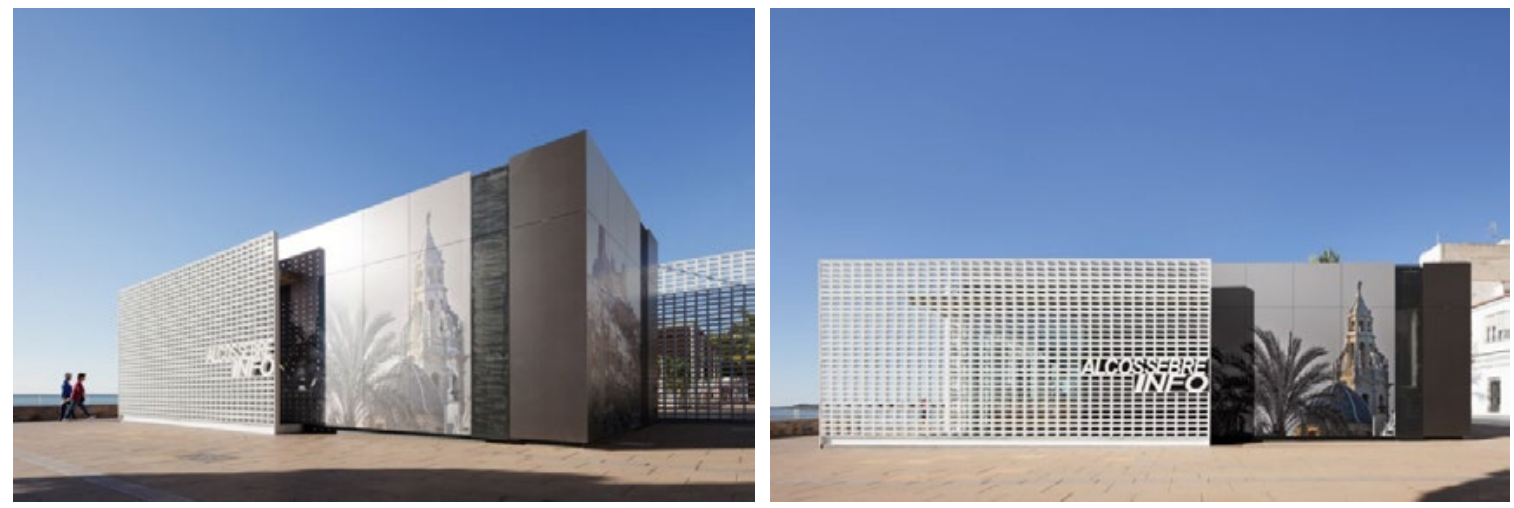

Fig. 12. Promenade and tourist office in Alcossebre: https://www.porcelanosa.com/trendbook/en/the- $9^{\text {th }}$-porcelanosa-awards-completed-projects-mediterranean-freshness-at-paseo-vista-alegre-alcossebre/ [accessed on 20.11.2020] 
Promenade and tourist office in Alcossebre: this project addressed the intervention on the Paseo Vista Alegare and a tourism office, located in the coastal town of Alcossebre in Spain. It was realized in 2015 and won IX Porcelanosa Awards[21]. The architecture studio Sanahuja \& Partners presents ceramics as the common thread of this intervention with three different uses: latticework, pavements and facades. Architects decided to bet on the ceramic product for this intervention, using three very different types of ceramic, with different thicknesses, formats, colors, finishes and uses, which makes the project very interesting from the technical and architectural point of view. A white glazed ceramic lattice was placed forming 3 semi-transparent walls of different lengths around the building to give it more entity. For the Vista Alegre promenade flooring, a technical porcelain tile was chosen. The third ceramic piece was the technical full body porcelain from the Porcelanosa Group and it was used to create a ventilated façade, a second skin over the tourist office. This facade also purifies the air by eliminating NOx.
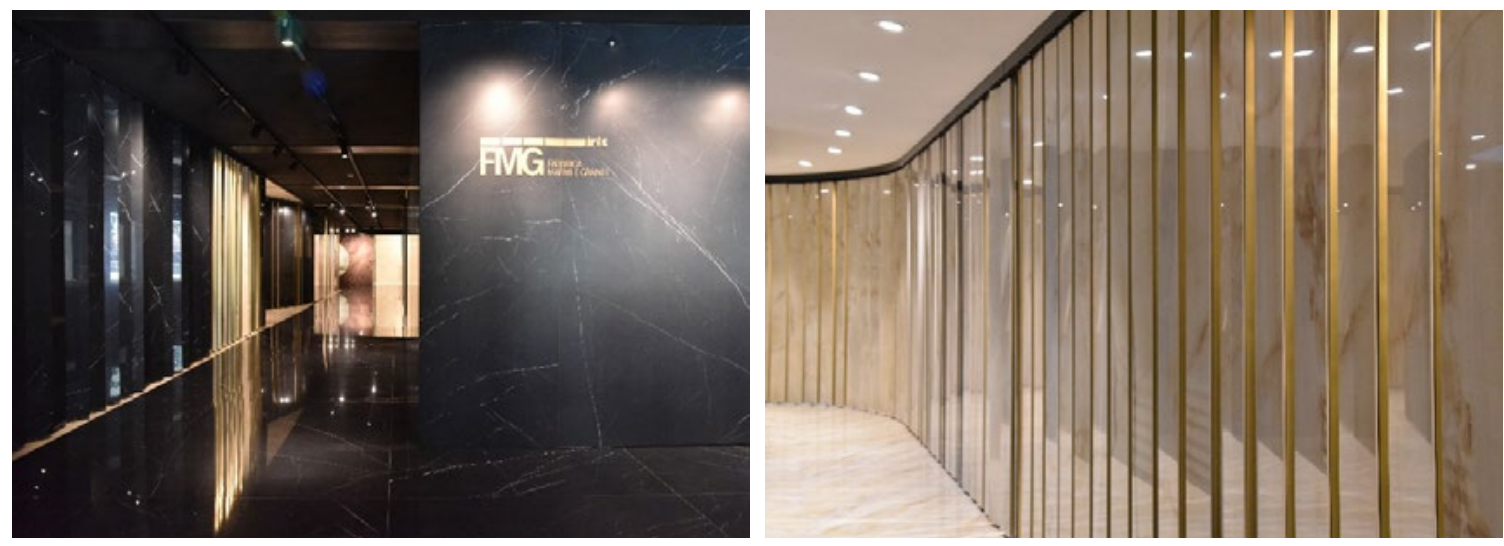

Fig. 13. Showroom FMG. (Source: the Author's own archives)

Showroom Iris Ceramica and FMG Fabbrica Marmi e Granitti was executed by Area17 studio in 2017. Large tiles from the MaxFine collection were demonstrated on movable panels creating mobile frames in which subsequent designs appear. Attention is drawn particularly to the presentation of the innovative application of large format tiles and their advantages - Casa FMG [22]. It is a design that shows specific spaces of a house implemented using tiles from the MaxFine collection. It shows how this material breaks the barriers between surfaces for architecture and furnishing. The tiles are big size and very thin, durable and light. They serve as coverings of floors, walls and also furniture and interior design elements [23]. This material of the future combines both functional and aesthetic advantages. The presented examples refer to a wider spectrum of possibilities for using porcelain stoneware tiles in interior design projects, where the entire decoration is based on the play of colours and textures of slab surfaces. This study was consistently designed using one material.
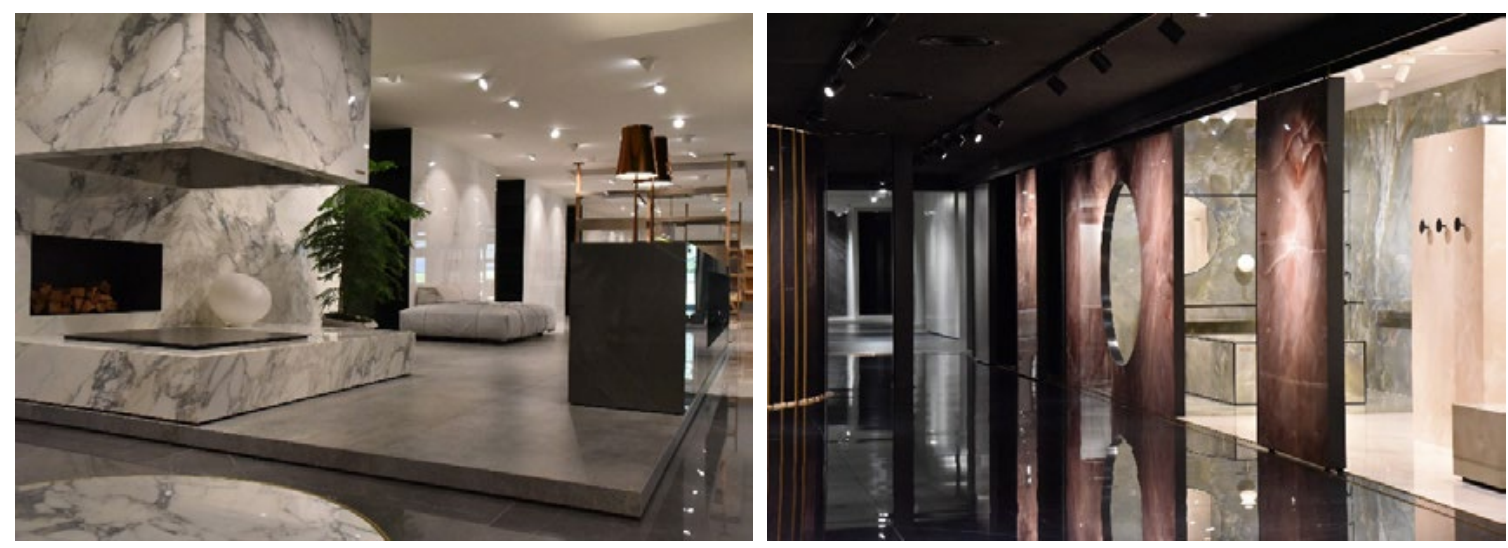

Fig. 14. Showroom FMG. (Source: the Author's own archives) 
These are different solution presenting a wide range of products where ceramic surfaces transgress their traditional boundaries and enter into new areas, from architecture to interiors, from structures to furniture, from floors to accessories. Which is important is the fact that this exceptionally resistant and compact material offers a vast range of applications and its parameters and beauty remain unaltered.

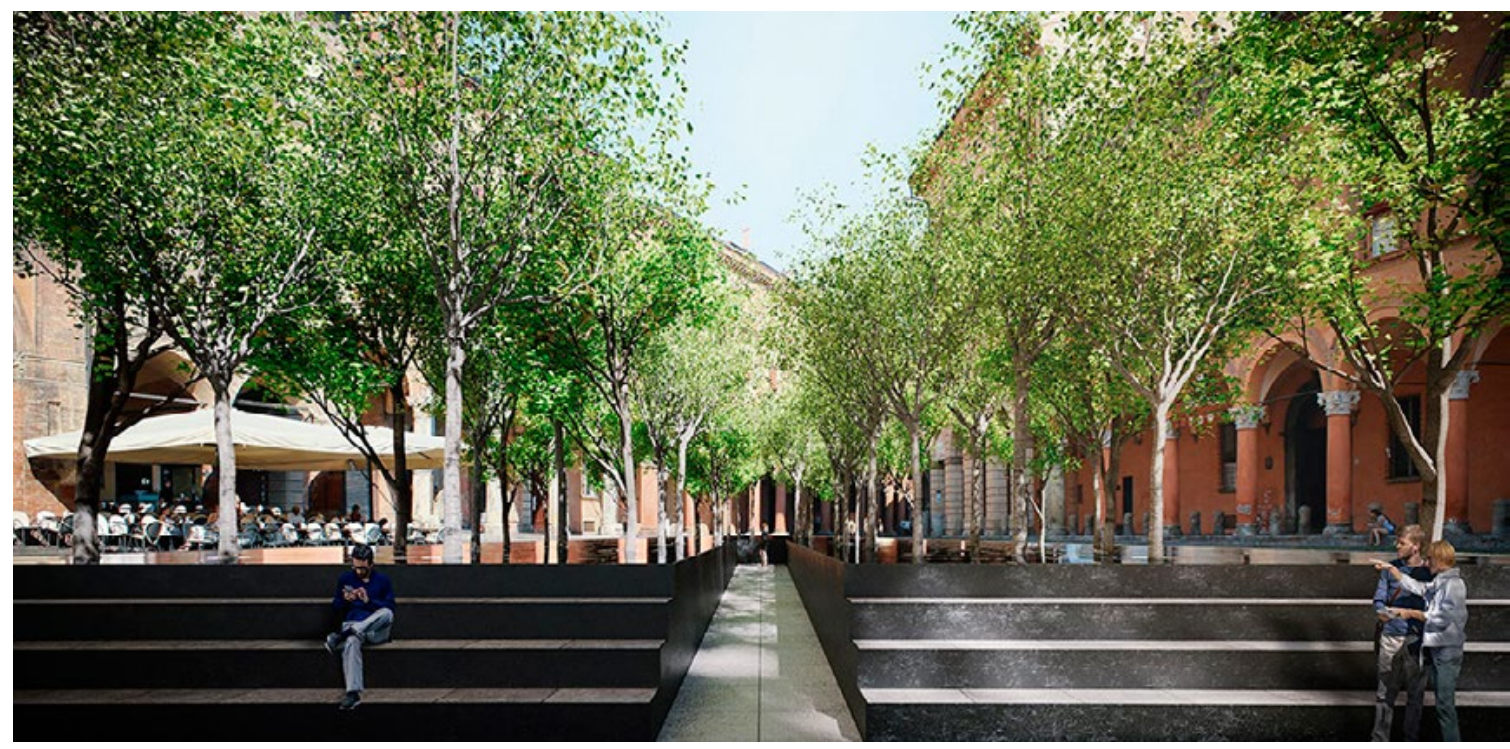

Fig. 15. Pollution 2018 - RefleAction: https://www.irisceramicagroup.com/en/media/from-pollution-to-refleaction-thefocus-is-on-the-iris-ceramica-group-once-again-in-the-atmospheric-setting-of-piazza-santo-stefano-bologna/ [accessed on 20.11.2020]

Pollution 2018 - RefleAction, it's a project at the intersection of architecture, art and landscape which amplifies the perception of urban space as a place of reconciliation between man and nature. This temporary installation was created on Piazza Santo Stefano in Bologna, in connection with Cersaie 2018. It was designed by the young professionals of the post-graduate academy SOS School of Sustainability, founded in Bologna by Mario Cucinella [24]. From the artificial ground created by a large reflecting ceramic tiles, 40 young oaks emerge mapping out the road of reflection on important environmental themes. This installation build the surfaces of the narrativepathway, that aims to subvert the usual relationship between the city and nature. Active Clean Air \& Antibacterial Ceramic ${ }^{\mathrm{TM}}$ technology applied on ceramic tiles becomes a reference to nature, material becomes a nature.
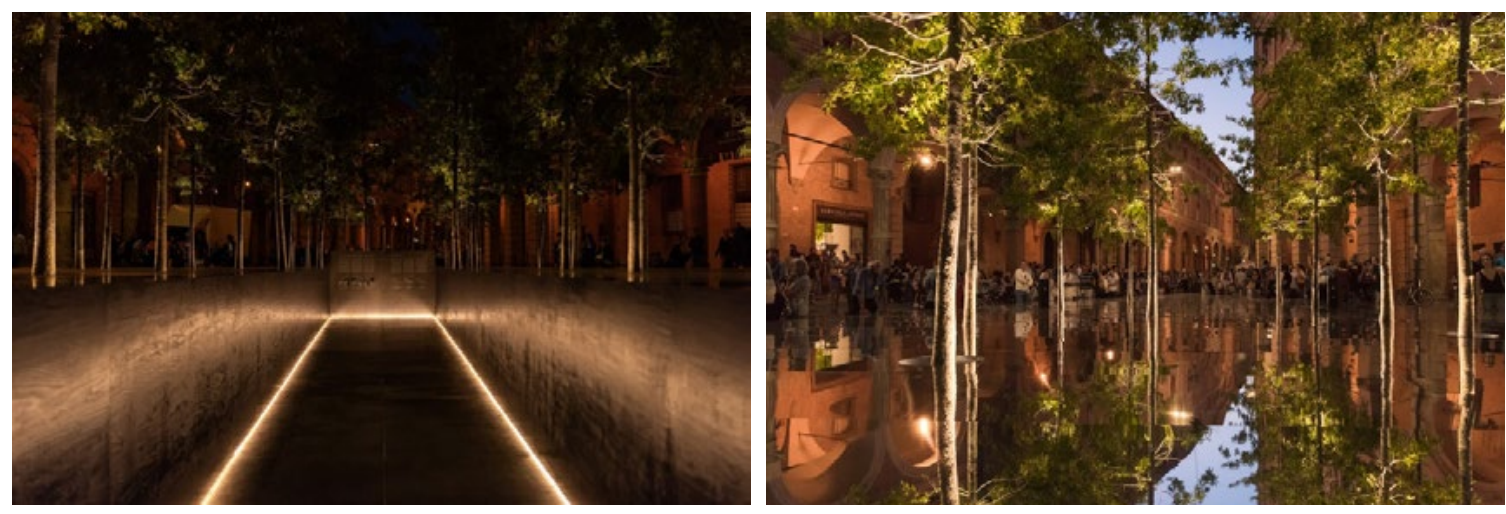

Fig. 16. Pollution 2018 - RefleAction: https://fondazione.irisceramicagroup.it/impegni/arte-cultura/pollution [accessed on 20.11.2020] 
These are different solution presenting a wide range of products where ceramic surfaces transgress their traditional boundaries and enter into new areas, from architecture to interiors, from structures to furniture, from floors to accessories. Which is important is the fact that this exceptionally resistant and compact material offers a vast range of applications and its parameters and beauty remain unaltered.

\section{Conclusions}

The potential of innovative ceramic materials has changed the way of thinking about design; new products give unconventional possibilities regarding project execution and a wider scope of application. Once available only in specific one-colour options, today this material offers a surprisingly wide range of patterns and texture that imitate stone, marble, wood, concrete or steel. At present, the usage of full body ceramic tiles in architectural projects manifests its exceptional technical and functional properties. Unquestionably, this product was ahead of its time compared to other ceramic materials due to its one-of-a-kind technical and utility properties, as well as due to the increasing availability of various sizes and aesthetic solutions.

The presented examples of various executed projects show solutions whose significant aspect was the use of siliceous sinter tiles as an innovative stand-out element that forms the architecture, the interior and furnishings. Another important aspect was a reference to the technology and functionality of porcelain stoneware. Projects that are executed nowadays that use the potential of innovative ceramic materials such as the porcelain stoneware are surprisingly original. They prove that it is the material of the future that offers the possibility of creating with the designer's imagination being the sole limitation. Spectacular projects constructed using large format full body ceramic tiles made a big step forward into the field of architectural projects as a central design element.

\section{References}

[1] Martin Bechthold, Anthony Kane, Nathan King, Ceramic material systems, Birkhauser, Basel 2015, s. 41, $112-114$.

[2] Oskar Jursza, Gres,spieki kwarcowe. Technicznie i praktycznie, Oskar Jursza 2018, źródło: https://www.scribd.com/ book/379510029/Gres-Spieki-Kwarcowe-Technicznie-i-praktycznie

[3] Anna Poddębniak, Opracowanie nowej gamy płytek o wysokiej odporności na ścieranie z wykorzystaniem innowacyjnego systemu barwienia masy, Materiały Ceramiczne/Ceramic Materials/, 71, 1, (2019), s. 71-78.

[4] Maciej Pawlik, Opracowanie nowej gamy ptytek wielkoformatowych z wykorzystaniem walcowego procesu prasowania, Materiały Ceramiczne/Ceramic Materials/, 71, 1, (2019), s. 79-87.

[5] Ferdynand Gacki, Wybrane właściwości użytkowe pytek typu gres porcellanato, Materiały Ceramiczne/Ceramic Materials/, 63, 2, (2011), s. 301-309.

[6] Tacjana Pazura, Wpływ nowoczesnych technologii produkcji gresów na design i trendy w architekturze wnętrz, Wokół Płytek Ceramicznych 2017/3

[7] Tacjana Pazura, Wielkoformatowy gres porcelanowy XXL - produkt XXI wieku, Wokół Płytek Ceramicznych, 2016/1

[8] https://www.sacmi.it/en-US/ceramics/Tiles/Continua [accessed on 24.02.2020]

[9] https://muratordom.pl/wnetrza/prace-wykonczeniowe/gres-techniczny-gres-do-garazu-aa-sdN8-UE8X-BLKP.html [accessed on 24.02.2020]

[10] https://www.oskarjursza.com/2018/01/czy-spieki-kwarcowe-sa-gresem.html [accessed on 24.02.2020]

[11] https://www.irisfmg.com/, https://www.granitifiandre.com/, https://www.coverlambygrespania.com/, https://ceramic. libet.pl/, http://www.laminam.pl/ [accessed on 24.02.2020]

[12] http://www.laminam.pl/ [accessed on 24.02.2020]

[13] http://hk.toto.com/en/technology/Hydrotect/15 [accessed on 24.02.2020]

[14] https://www.irisfmg.com/doc/cataloghi_catalogues/1general_fmg_maxfine.pdf [accessed on 24.02.2020]

[15] https://www.casalgrandepadana.com/en/magazine/detail/casalgrande-padana-e-kengo-kuma-realizzano-casalgr/ opens [accessed on 20.11.2020]

[16] https://www.granitifiandre.com/news/new-maximum-showroom-opens [accessed on 20.11.2020] 
[17] https://www.casalgrandepadana.com/en/magazine/detail/casalgrande-ceramic-crown-daniel-libeskind-il-land/opens [accessed on 20.11.2020]

[18] https://www.casalgrandepadana.com/en/magazine/detail/successo-delle-lastre-casalgrande-padana-con-vanke/ [accessed on 20.11.2020]

[19] https://www.casalgrandepadana.com/en/projects/r/montebar-villa-jm-architecture-jacopo-mascheroni/ [accessed on 20.11.2020]

[20] https://issuu.com/casalgrandepadana/docs/2016_creative_book_casalgrande_pada/121 [accessed on 20.11.2020]

[21] https://www.porcelanosa.com/trendbook/en/the-9 ${ }^{\text {th }}$-porcelanosa-awards-completed-projects-mediterranean-freshness-at-paseo-vista-alegre-alcossebre/ [accessed on 20.11.2020]

[22] https://www.irisceramica.com/projects/iris-ceramica-showroom [dostęp 20.11.2020]

[23] https://www.irisfmg.com/porcelain-tile/maxfine/marmi-maxfine [dostęp 20.11.2020]

[24] https://www.irisceramicagroup.com/en/media/from-pollution-to-refleaction-the-focus-is-on-the-iris-ceramica-group-once-again-in-the-atmospheric-setting-of-piazza-santo-stefano-bologna/ [accessed on 20.11.2020]

\title{
Wielkoformatowe projektowanie: płyty gresowe i ich zastosowanie w projektowaniu architektoniczym
}

\begin{abstract}
Abstrakt: W XXI wieku nastąpił wyraźny rozwój technologii produkcji płyt gresowych. Wzrosły możliwości technologiczne oraz zakres zastosowania tego materiału. W architekturze płyty gresowe zaczęły pojawiać się już nie tylko jako materiał okładzinowy dla betonu ale również w nie kojarzonych dotąd z płytami gresowymi zastosowaniach. Niniejszy artykuł skupia się na ujęciu tego tematu w kontekście zastosowania wielkoformatowych płyt kamionki porcelanowej w kształtowaniu architektury. Współcześnie doświadczamy niezwykłej rewolucji, zarówno technicznej, jak i estetycznej, w produkcji materiałów ceramicznych, a konkretnie płyt gresu porcelanowego. Nowoczesne produkty ceramiczne, zwłaszcza wielkoformatowe płyty gresowe, zwane też spiekami kwarcowymi, dają niekonwencjonalne możliwości projektowe i rozszerzony zakres stosowania tego materiału w realizacjach architektonicznych.
\end{abstract}

Słowa kluczowe: architektura, innowacyjne technologie ceramiczne, gres porcellanato, kamionka porcelanowa, spieki kwarcowe, wielkoformatowe płyty gresowe 